\title{
Fake News, Confirmation Bias, the Search for Truth, and the Theology Student
}

by William Badke

\section{Abstract}

In an era in which the reliability of many kinds of information is in question, the theological library has a crucial role to play in guiding students in their evaluation of the resources available to them both within and outside of our collections. Confirmation bias creates a strong obstacle, as does the tendency for theological students to create fortresses of belief that prevent them from fully engaging with all views and evaluating them both openly and effectively. While students may have varying opinions about the possibility of finding truth, they need to discover the best means to come to a strong measure of certainty.

\section{Introduction}

It is almost impossible to miss the "fake news" debate that is raging in many places. This phenomenon could be seen as an extreme manifestation of the high level of subjectivity that characterizes our postmodern age. Yet the very fact that there have been so many voices raised against falsehood makes it clear that all is not well and that even postmodernism has its limits.

For theological students, who are often steeped in notions of truth and belief, the challenge of a society torn apart by opinion, along with the sharing of wild theories, is a serious one. Right in the center of the battle against falsehood are professors and librarians. The theological library, in particular, has long seen itself as a bastion of reason in the face of competing truth claims. While we may have varying views of our roles, librarians are fundamentally concerned about the exercise of "truth."

\section{The Basis for Evidence and Truth}

It has long been a reality that belief systems vary among Christian theological institutions. The same is true for other religious systems or even views that reject religion. All such worldviews share a common desire for a form of certainty, though they are unlikely to come to agreement. Thus, it is probable that one school's definition of truth will be another school's definition of error. Is there any foundation upon which it is possible or even recommended that we evaluate truth claims? Some point to the bedrock of Scripture, inerrant (or at least infallible, depending on the school), which makes them able to rule on competing claims. Others see the Bible as a possible guide to truth but not in an absolute sense.

Instead of debating one another's definitions of biblical authority, we could ask, "Does the Bible itself consider the use of evidence as an important means to come at truth, or at least a measure of certainty?" My reading shows that it does indeed do that. Consider the following:

1. The Book of Job, as misguided as some of the arguments of its main characters may have become, works on the premise that the known must be used as a basis to explore the unknown.

2.Zechariah 8:16-17 argues that God approves truth based upon sound judgment and rejects plots and false testimony.

3. Acts 17:11 declares that the Bereans were of more noble character because they investigated Paul's words to see if they were true.

William Badke is Associate Librarian for Associated Canadian Theological Schools and Information Literacy at Trinity Western University, Langley, BC, Canada. 
4.Paul based his apologetic for the resurrection in 1 Corinthians 15 solely upon the evidence of eyewitness testimony.

The Bible, whatever level of authority we give it, emphasizes enlisting evidence to make our decisions intelligently and opposes trusting in unverified beliefs or following rabbit holes into conspiracies and unfounded notions.

\section{Confirmation Bias}

An increasing body of research is making it plain that our supposed dispassionate rationalism by which we make decisions based on evidence is in good measure an illusion. ${ }^{1}$ We are plagued by a tendency toward confirmation bias, by which we give greater credence to evidence that supports our existing beliefs, and we discount contradictory voices. None of us are immune from such bias. It supports our propensity to fall for fake social media reports that confirm our present views. It also causes us to downplay academic evidence that contradicts our current beliefs, even as we buy into potentially faulty evidence that agrees with our position.

What confirmation bias means in practice is that we are highly unlikely to change our positions on anything we consider important. Why? In a 2017 article I suggested two possible explanations. ${ }^{2}$ First, all of us cope with the many voices speaking into our experience by developing a worldview, a personal explanation of the way things are. We need that explanation to avoid fragmenting our lives into a multitude of often contradictory explanations. When views come to us that attack that explanation, or call on us to modify it, we become anxious. Our personal need for self-preservation sets in, and so we tend to dismiss the contradiction and rely on our overarching worldview. Alternatively, when we find evidence that supports our existing beliefs, we give it greater weight.

The second possible explanation is that there are too many competing voices out there. We can't embrace them all without fragmenting ourselves, so we make a choice, even if we don't construct an actual worldview. Once the choice is made, we resist competing voices which would tell us that we made the wrong choice. Unless we want to live with permanent uncertainty, we will stick to our guns, affirming evidence that reinforces our choice and discounting evidence that does not.

What confirmation bias does, unfortunately, is to entrench us, preventing us from giving credence to any data but that which confirms our current position. The result is polarization, which, if we are not careful, can have us firmly supporting a lie simply because the truth doesn't fit within the choices we have previously made.

\section{Can We Even Find the Truth?}

Nathan Rinne, an academic librarian at Concordia Saint Paul in Saint Paul, MN, has argued that the "Authority" concept in the ACRL Framework for Information Literacy in Higher Education is flawed because it views authority as constructed, rather than emphasizing that a determination of authority demands a search for the truth. ${ }^{3}$ Over time, he and I have engaged in a friendly debate over his position. ${ }^{4} \mathrm{He}$ is uninterested in giving up the view that all of us must seek the truth. My approach is that, while this is a lofty goal, our pluralistic world requires us to seek something closer to reasoned confidence, because we will never find complete consensus or even be able to prove absolutely that our truth is universal truth. I e-mailed the following to Nathan: "I personally believe in truth. But definitions of it, as you say, are pretty much impossible to agree on.”

${ }^{1}$ For example, Robert J. MacCoun, "Biases in the Interpretation and Use of Research Results," Annual Review of Psychology 49, no. 1 (1998): 259-287; Raymond S. Nickerson, "Confirmation Bias: A Ubiquitous Phenomenon in Many Guises," Review of General Psychology 2, no. 2 (1998): 175; Axel Westerwick, Benjamin K. Johnson, and Silvia KnoblochWesterwick, "Confirmation Biases in Selective Exposure to Political Online Information: Source Bias vs. Content Bias," Communication Monographs 84, no. 3 (2017): 343-364.

${ }^{2}$ William Badke, "Post-Truth, False News, and Information Literacy," Online Searcher 41, no. 4 (July-August, 2017): 57-59.

${ }^{3}$ Nathan Aaron Rinne, "The New Framework: A Truth-Less Construction Just Waiting to be Scrapped?” Reference Services Review 45, no. 1 (2017): 54-66.

${ }^{4}$ See, for example, "My Response to Librarian Bill Badke's Defense of 'Authority is Constructed and Contextual," February 23, 2017. https://reliablesourcessite.wordpress.com/2017/02/23/my-response-to-librarianbill-badkes-defense-of-authority-isconstructed-and-contextual// 
I went on to argue that we have alternatives: a radical postmodernism (that sees everything as subjective so that neither consensus nor truth is possible) and the scholarly methods we have long used to determine authority. The former leads to a world in which speculation and paranoia drive "knowledge," and verification is a bad word. The latter gives us the means to verify claims with agreed-upon norms.

To say "Authority is constructed" does not in any way imply that there is no method to the construction. In fact, the very essence of scholarship is the set of careful methodologies we have developed to help us determine what we should believe. We can find agreement on many things despite the diversity of our views. Our information environment is not one of ever questioning and never finding resolution. Scholarship is a quest with a goal. Method drives that goal, or we are doomed.

I could hope that everyone would define truth in the same way (so that it could actually be truth), but I don't see that happening. What I hope for, instead, is that we will use our conversations, our methodologies, our authority construction work, to find a path to agreement about many things, while continuing to do battle over others. The enemy at the gates today is conjecture and speculation masquerading as authority. ${ }^{5}$

There are methods, sound methods, which give us a measure of certainty if we use them correctly. My greater fear, within our confirmation-biased, paranoid world, is that we will abandon method in favor of a reliance upon personal opinion. Can we find truth? I hope so, but for now I would rather assert the power of sound research method to keep us all on the same wavelength, so that our discourse can be solidly founded. If truth emerges, fine. But we may have to settle for greater degrees of agreement on the basis of good evidence.

\section{What Should We Tell Our Students?}

The theological library, and its librarians, have a vital role to play in guiding our students to avoid falsehood and seek a surer foundation. Not only do we have credible resources available, but we engage in at least some measure of instruction that provides opportunity for us to promote to our students agreed-upon methods to seek credible findings for research problems.

A brilliant academic blog post by Scott Kaufman, “The Pressing Need for Everyone to Quiet Their Egos,” makes a solid case for moving beyond our silos and impasses in research and belief. ${ }^{6} \mathrm{He}$ posits four principles: Detached Awareness (parking your ego to remain open to hearing competing evidence), Inclusive Identity (the ability to identify with others who are speaking to divergent views), Perspective-Taking (paying attention to our interdependence, thus increasing empathy), and Growth-mindedness (seeing the interaction of views as less a threat to our existence than as a path to progress). Recent research shows the benefit to quieting the ego for interpersonal understanding. ${ }^{7}$

But at least of some of our students are going to react strongly to this more open approach to discourse. Scholarship may be a conversation, they say, but we are theology students. Truth is our byword, and we know the truth. To encourage us to park our egos, empathize with the views of others, and even be prepared to have our positions overturned by stronger counterarguments seems anathema to being a true believer.

This kind of thinking speaks to a fear we all experience, a fear that is at the heart of confirmation bias: If we open the door to the counter-arguments of others, we could be undone, shown to be wrong about our fundamental beliefs, doomed to find that our past lives were based on inaccuracy. It's the intellectual and moral equivalent of fearing that we will have our foundation kicked out from under us. I know what I know, we say. Please don't confuse me with your obviously flawed ideas.

5 Ibid.

${ }^{6}$ Scott Barry Kaufman, "The Pressing Need for Everyone to Quiet Their Egos," Scientific American, Beautiful Minds Blog, May 21, 2018. https://blogs.scientificamerican.com/beautiful-minds/the-pressing-need-for-everyone-to-quiet-their-egos/.

${ }^{7}$ Heidi A. Wayment, and Jack J. Bauer, "The Quiet Ego: Motives for Self-Other Balance and Growth in Relation to WellBeing," Journal of Happiness Studies 19, no. 3 (2018): 881-896. 
Theology students can inhabit some very strong fortresses. Fortresses are helpful when falsehood reigns, but they can become the enemy of truth when their inhabitants don't test their beliefs outside of the castle where real people live. How do I know that the views I cherish, or that the Twitter post confirming that $\mathrm{X}$ or $\mathrm{Y}$ are conspiring against us, won't ultimately be found to be wrongheaded? Staying in the "fortress" is comfortable, because it gives us confidence, but it provides us no opportunity to determine whether our comfort zone is true or false.

What should we tell our students? Tell them that, if they truly believe they are right, entering into dialogue with others is both a means to measure the power of their beliefs and, through understanding other points of view, a way of refining those beliefs. James Luther Adams wrote, "An unexamined faith is not worth having, for it can be true only by accident. A faith worth having is a faith worth discussing and testing." ${ }^{\prime}$ There is no value to theological scholarship that, like a tank run amok, bashes through the opposition without ever recognizing anyone it has crushed.

Tell your students that they have methods available to them to test truth-claims and make well-reasoned conclusions. For Christian students, tell them to be like the Bereans who went home and examined the evidence to ensure that what they heard was actually so (Acts 17:11). Tell them to park their egos, go past their fears, and engage in discourse even with views they find abhorrent. Tell them to challenge and question and investigate until they find certainty, or at least a good amount of confidence.

We may never in this life find universal consensus on many things, yet we can find a measure of certainty not as a confirmation of our biases, but as a result of careful investigation and a reliance upon grounded evidence.

${ }^{8}$ James Luther Adams, The Prophethood of All Believers (Boston: Beacon Press, 1986), 48. 